\title{
Identification of natural products as novel ligands for the human $5-\mathrm{HT}_{2 \mathrm{C}}$ receptor
}

\author{
Yao Peng ${ }^{1,2,3,4}$, Simeng $\mathrm{Zhao}^{3}$, Yiran $\mathrm{Wu}^{3,5}$, Haijie Cao ${ }^{6,7}$, Yueming $\mathrm{Xu}^{3}$, \\ Xiaoyan Liu ${ }^{3}$, Wenqing Shui ${ }^{3,5}$, Jianjun Cheng ${ }^{3}$, Suwen Zhao ${ }^{3,5}$, \\ Ling Shen ${ }^{3,5}$, Jun $\mathrm{Ma}^{8}$, Ronald J. Quinn ${ }^{8}$, Raymond C. Stevens ${ }^{3,5}$, \\ Guisheng Zhong ${ }^{3,5 \bowtie}$, Zhi-Jie Liu ${ }^{1,2,3,5 \bowtie}$ \\ ${ }^{1}$ National Laboratory of Biomacromolecules, Institute of Biophysics, Chinese Academy of Sciences, Beijing 100101, \\ China \\ ${ }^{2}$ Institute of Molecular and Clinical Medicine, Kunming Medical University, Kunming 650500, China \\ 3 iHuman Institute, ShanghaiTech University, Shanghai 201210, China \\ ${ }^{4}$ University of Chinese Academy of Sciences, Beijing 100049, China \\ ${ }^{5}$ School of Life Science and Technology, ShanghaiTech University, Shanghai 201210, China \\ ${ }^{6}$ College of Pharmacy, Nankai University, Tianjin 300071, China \\ ${ }^{7}$ High-throughput Molecular Drug Discovery Center, Tianjin Joint Academy of Biotechnology and Medicine, \\ Tianjin 300457, China \\ 8 Eskitis Institute for Drug Discovery, Griffith University, Brisbane, QLD 4111, Australia
}

Received: 28 March 2017 / Accepted: 15 May 2017 / Published online: 9 March 2018

\begin{abstract}
G protein-coupled receptors (GPCRs) constitute the largest human protein family with over 800 members, which are implicated in many important medical conditions. Serotonin receptors belong to the aminergic GPCR subfamily and play important roles in physiological and psychological activities. Structural biology studies have revealed the structures of many GPCRs in atomic details and provide the basis for the identification and investigation of the potential ligands, which interact with and modulate the receptors. Here, an integrative approach combining a focused target-specific natural compound library, a thermalshift-based screening method, affinity mass spectrometry, molecular docking, and in vitro as well as in vivo functional assay, was applied to identify (-)-crebanine and several other aporphine alkaloids as initial hits for a human serotonin receptor subtype, the $5-\mathrm{HT}_{2 \mathrm{C}}$ receptor. Further studies illuminated key features of their binding affinity, downstream signaling and tissue reaction, providing a molecular explanation for the interaction between (-)-crebanine and human $5-\mathrm{HT}_{2 \mathrm{C}}$ receptor.
\end{abstract}

Keywords GPCR, 5- $\mathrm{HT}_{2 \mathrm{C}}$ receptor, Natural product, Alkaloids

Yao Peng and Simeng Zhao have contributed equally to this work.

$\bowtie$ Correspondence: zhongsh@shanghaitech.edu.cn (G. Zhong), liuzhj@shanghaitech.edu.cn (Z.-J. Liu) 


\section{INTRODUCTION}

G protein-coupled receptors (GPCRs) are cell surface receptors which are responsible for more than $80 \%$ of cell signal transduction across cell membranes. They are involved in a wide range of physiological as well as psychological activities and constitute the largest human protein family with over 800 members. GPCRs are implicated in many medical conditions such as heart disease, metabolic diseases, cancer, immune diseases and neurological disorders (Rask-Andersen et al. 2014). Drugs targeting GPCRs comprise as much as 33\% of all marketed drugs approved by FDA (U.S. Food and Drug Administration) (Santos et al. 2017).

Serotonin, or 5-hydroxytryptamine (5-HT), is a neurotransmitter widely found in both the central nervous system (CNS) and the peripheral nervous system. It plays important roles in the functions of brain, gastrointestinal tract, cardiovascular system, and immune cells. In the CNS, serotonergic system regulates mood, perception, memory, food intake, sexual behaviors, and other functions. These physiological roles of serotonin are mediated by serotonin receptors, which are composed of fourteen subtypes in the mammalian system that are further grouped into seven subfamilies (5- $\left.\mathrm{HT}_{1-7}\right)$. Except for $5-\mathrm{HT}_{3}$, which functions as a ligandgated ion channel, all other serotonin receptors belong to the GPCR superfamily (McCorvy and Roth 2015).

Among serotonin receptors, the $5-\mathrm{HT}_{2 \mathrm{C}}$ receptor belongs to the $5-\mathrm{HT}_{2}$ subfamily. It shares $58 \%$ and $55 \%$ sequence similarity with the $5-\mathrm{HT}_{2 \mathrm{~A}}$ and $5-\mathrm{HT}_{2 \mathrm{~B}}$ receptors, respectively (Isberg et al. 2016). Activation of 5- $\mathrm{HT}_{2 \mathrm{C}}$ receptor is believed to reduce appetite (Halford and Harrold 2012) and cure schizophrenia (Cheng et al. 2016). In 2012, lorcaserin, a selective $5-\mathrm{HT}_{2 \mathrm{C}}$ agonist, was approved by the FDA for the treatment of obesity (Narayanaswami and Dwoskin 2016). Its efficacy in treatment of nicotine addiction is currently being evaluated in clinical trials (Zeeb et al. 2015). Moreover, 5- $\mathrm{HT}_{2 \mathrm{C}}$ has been demonstrated as a potential therapeutic target for treatment of mental disorders also (Englisch et al. 2016). Agomelatine, antagonist of $5-\mathrm{HT}_{2 \mathrm{C}}$ receptor, is used for treating depression and schizophrenia (Jacobson 2015).

The ligand-binding pockets of all serotonin receptors are very similar and, therefore, it is difficult to design an inhibitor exhibiting high degree of specificity for a particular serotonin receptor. Most of the marketed drugs targeting serotonin receptors have side effects which arise due to low specificity. For drug candidates targeting the $5-\mathrm{HT}_{2 \mathrm{C}}$ receptor, achieving high selectivity is very important because non-specific interaction of the drug with the other two $5-\mathrm{HT}_{2}$ receptors causes side effects or toxicities. Unwanted activation of $5-\mathrm{HT}_{2 \mathrm{~A}}$ by drugs targeting the $5-\mathrm{HT}_{2 \mathrm{C}}$ receptor causes hallucinations (Nichols et al. 2002). Similarly, non-specific activation of $5-\mathrm{HT}_{2 \mathrm{~B}}$ leads to valvular heart disease (Connolly et al. 1997).

Ligand identification for GPCRs is a tedious, timeconsuming and resource intensive process. In the past few years, new assay methods have been developed to explore multidimensional chemical space in a much more efficient manner. These methods range from cellbased (Besnard et al. 2012), label-free (e.g., Surface Plasmon Resonance; SPR, and Isothermal Titration Calorimetry; ITC), new biosensors (Kroeze et al. 2015) to in silico screening (Huang et al. 2015), which has significantly increased the success rate of hit identification when compared to traditional methods.

Natural products contain chemical compounds or substances with pharmacological or biological activities, which can be harnessed for therapeutic benefit or treating diseases as exemplified by traditional Chinese medicine (All natural 2007). In the development of modern medicines, natural products are often used as starting points for drug discovery and have been considered as the most important resource for identification of lead compounds due to their diverse molecular architectures and a wide range of bioactivities (Ahn 2016). Consequently, during the past 30 years, natural products have been instrumental in the discovery of more than half of the approved drugs (Newman and Cragg 2016).

Given the challenges involved in GPCR ligand discovery; in particular, the need to screen a large chemical space, one efficient approach for identifying hits would be to design or select focused screening libraries to reduce the workload. In this study, as the $5-\mathrm{HT}_{2 \mathrm{C}}$ receptor belongs to monoamine type of receptors in the class $\mathrm{A}$ of GPCR family, we decided to screen novel ligands from alkaloids containing basic nitrogen atoms. The positively charged nitrogen atom of the ligand was expected to anchor to the highly conserved $\mathrm{D}^{3.32}$ of the aminergic receptors. The initial screening was performed using thermal stability assay (Alexandrov et al. 2008) against a focused alkaloid library consisting of over 300 chemical components isolated from plants (Shang et al. 2010). (-)-Crebanine and several other aporphine alkaloids were identified as potential hits for the $5-\mathrm{HT}_{2 \mathrm{C}}$ receptor. The affinity mass spectrometry (MS) method was used to validate the hits and measure the binding affinities (Chen et al. 2015; Qin et al. 2015). The cell-based calcium influx assay was employed to characterize the function of the validated hits. Molecular docking studies coupled with site directed mutagenesis were used to predict the binding sites for the compound. A patch clamp experiment was also utilized to investigate the compound's physiological effects in neurons. 


\section{RESULTS}

\section{Aporphine alkaloids as potential ligands for 5-HT $2 \mathrm{C}$ receptor}

In order to obtain conformationally homogeneous, thermo-stable and highly pure protein samples for screening and characterization of potential ligand hits, the expression construct of $5-\mathrm{HT}_{2 \mathrm{C}}$ receptor was optimized as described previously (Lv et al. 2016). The final expression construct contains a BRIL (PDB ID 1M6T, MW $11.9 \mathrm{kDa}$ ) as a stabilizing fusion partner inserted in receptor's third intracellular loop (ICL3) between L246 and Q301. Additionally, the N- and C-terminals were truncated by 39 and 65 residues, respectively. The optimized construct was inserted into a pFastbac vector for expression in Spodoptera frugiperda (Sf9) cells.

A small pipetting workstation (Qiagility, Qigen) and a real-time fluorescence quantitative PCR were used to perform the high throughput CPM (the thiol-specific fluorochrome N-[4-(7-diethylamino-4-methyl-3coumarinyl) phenyl] maleimide) screening (Alexandrov et al. 2008). Aporphine alkaloids (1-5) were identified as potential hits for $5-\mathrm{HT}_{2 \mathrm{C}}$ receptors (Fig. $1 \mathrm{~A}$ ). Among them, (-)-crebanine (1) and (+)-isocorydine (5) showed more significant binding property to $5-\mathrm{HT}_{2 \mathrm{C}}$ receptor, with the thermal shift value (the difference between target A and B for melting temperature in CPM assay, $\Delta \mathrm{Tm})$ of 9.25 and $4.82{ }^{\circ} \mathrm{C}$, respectively, comparing to apo-protein (Fig. 1B). The other three alkaloids, (-)-dicentrine (2), (+)-magnoflorine (3), and didehydroglaucine (4) showed slight temperature shift $\left(\Delta \mathrm{Tm}<1.00{ }^{\circ} \mathrm{C}\right)$ in the thermal shift experiments.

\section{Ligand validation by ultrafiltration-based affinity mass spectrometry analysis}

The ultrafiltration-based affinity MS technique has been established to search for ligands, verify binding and estimate affinity of specific ligands for given soluble protein targets (Chen et al. 2015; Qin et al. 2015). In this study, this technique was adapted to ligand-binding validation for the membrane $5-\mathrm{HT}_{2 \mathrm{C}}$ receptor. To confirm binding specificity of (-)-crebanine (1) and<smiles>COc1ccc2c(c1OC)C[C@@H]1[C@H]3CN(C)c4c5cc(c3c4[C@@H]21)OCO5</smiles>

1<smiles>COc1cc2c(cc1OC)-c1c3c(cc4c1[C@@H](C2)N(C)CC4)OCO3</smiles>

2<smiles>COc1ccc2c(c1O)-c1c(O)c(OC)cc3c1[C@@H](C2)N(C)CC3</smiles>

3<smiles>COc1cc2cc3c4c(cc(OC)c(OC)c4c2cc1OC)CCN3C</smiles>

4<smiles>COc1ccc2c(c1O)-c1c(OC)cc(OC)c(O)c1[C@@H]2C</smiles>

5

B

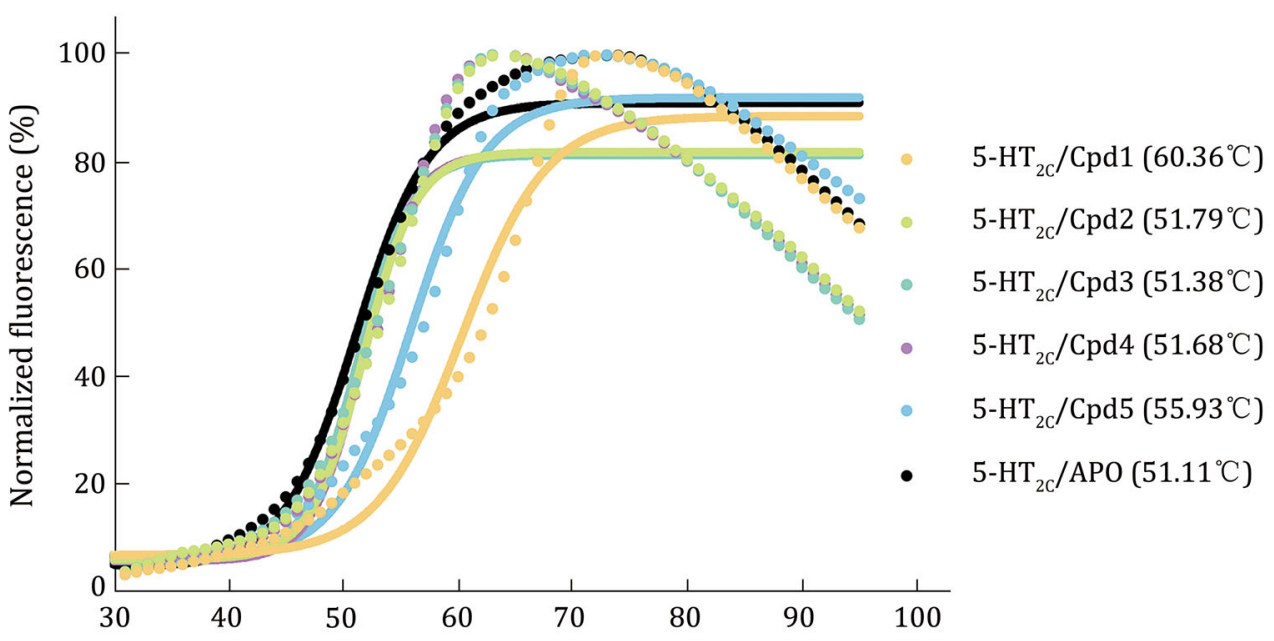

Fig. 1 A Structures of aporphine alkaloids. The five aporphine alkaloids: (-)-crebanine (1), (-)-dicentrine (2), (+)-magnoflorine (3), didehydroglaucine (4), (+)-isocorydine (5). B Thermo-stability values of aporphine alkalodis. Thermal stability ramping assay of 5-HT $2 \mathrm{C}$ receptor combine with aporphine alkalodis. The Tm value of the $5-\mathrm{HT}_{2 \mathrm{C}} /$ compound $\mathbf{1}$ (yellow trace) is higher than other combinations, indicating that $5-\mathrm{HT}_{2 \mathrm{C}}$ /compound 1 combination improves the thermostability of $5-\mathrm{HT}_{2 \mathrm{C}}$ receptor 
$(+)$-isocorydine $(5)$ to $5-\mathrm{HT}_{2 \mathrm{C}}$ receptor, a negative control was prepared using another GPCR protein (hydroxycarboxylic acid receptor 2 ). An $\mathrm{S} / \mathrm{C}$ ratio referring to the ratio of MS response of a given ligand detected in the $5-\mathrm{HT}_{2 \mathrm{C}}$ receptor incubation sample versus the control was used to assess specific enrichment of the ligand associated with $5-\mathrm{HT}_{2 \mathrm{C}}$ receptor. Previous study has shown that ligands with an S/C ratio $>2$ are positive binders of the target protein (Chen et al. 2015). For $(-)$-crebanine (1) and (+)-isocorydine (5), their S/C ratios are significantly above the threshold and very close to a known high affinity $5-\mathrm{HT}_{2 \mathrm{C}}$ receptor antagonist ritanserin, indicating that they both showed obvious interactions with $5-\mathrm{HT}_{2 \mathrm{C}}$ receptor (Table 1). The high-resolution mass spectra for both compounds in the protein complex fraction confirmed their structural identification (Fig. 2). Then, a single-point $K_{\mathrm{d}}$ calculation method (Qin et al. 2015) was employed to estimate binding affinity of each ligand to the receptor (Table 1). It turned out that (-)-crebanine (1) displayed stronger affinity $\left(K_{\mathrm{d}} \sim 0.34 \mu \mathrm{mol} / \mathrm{L}\right)$ than its analog (+)-isocorydine (5) $\left(K_{\mathrm{d}} \sim 11 \mu \mathrm{mol} / \mathrm{L}\right)$ whereas the affinity of ritanserin (positive control) was in the high nmol/L range.

\section{Calcium influx assay characterization of the potential hits}

The $5-\mathrm{HT}_{2 \mathrm{C}}$ receptor mainly couples to $\mathrm{G}_{\alpha \mathrm{q}}$ proteins. The activated $5-\mathrm{HT}_{2 \mathrm{C}}$ receptor transmits the signals from the extracellular to the intercellular side using $\mathrm{DAG} / \mathrm{IP}_{3}$ (diacyl glycerol/inositol 1,4,5-trisphosphate) as its second massagers (Hannon and Hoyer 2008). $\mathrm{IP}_{3}$ stimulates the endoplasmic reticulum to release calcium ions into the cytoplasm, which causes the increase of calcium concentration in cytosol. Therefore, calcium mobilization assay is commonly applied to understand how unknown small molecule ligands of $5-\mathrm{HT}_{2 \mathrm{C}}$ receptor modulate cellular signal transductions. In this case, Fluo-4 Direct dye was used as a fluorescence indicator to detect calcium flux in $G$ protein-coupled receptor expressed cells. The fold of maximum response over average of basal reading is plotted against compound

Table $1 \mathrm{~S} / \mathrm{C}$ ratios and estimated binding affinity of two new ligands and ritanserin

\begin{tabular}{llll}
\hline & Compound 1 & Compound 5 & Ritanserin \\
\hline S/C & $9.15 \pm 1.43$ & $7.89 \pm 0.74$ & $8.39 \pm 1.80$ \\
$K_{\mathrm{d}}(\mu \mathrm{mol} / \mathrm{L})$ & $0.34 \pm 0.07$ & $11.0 \pm 0.75$ & $0.37 \pm 0.05$ \\
\hline
\end{tabular}

For each ligand, S/C and $K_{\mathrm{d}}$ measurements were represented by the average values and standard deviations from experimental replicates $(n=4)$ concentration to determine the potency of the compounds (Fig. 3). (-)-Crebanine (1) displayed antagonism for $5-\mathrm{HT}_{2}$ receptors (Fig. $3 \mathrm{~A}$ ). When $5-\mathrm{HT}_{2 \mathrm{~A} / 2 \mathrm{~B} / 2 \mathrm{C}}$ receptors were activated by $3 \mathrm{nmol} / \mathrm{L}$ of 5 -HT, (-)-crebanine (1) inhibited the activation at $I C_{50}$ at 564,1693 and $149 \mathrm{nmol} / \mathrm{L}$, respectively. (-)-Crebanine (1) showed higher efficacy with the $I C_{50}$ value in $5-\mathrm{HT}_{2 \mathrm{C}}$ receptor compared to $5-\mathrm{HT}_{2 \mathrm{~A}}$ and $5-\mathrm{HT}_{2 \mathrm{~B}}$ receptors. (-)-Crebanine (1)'s analog $(+)$-isocorydine (5) showed very weak partial agonism towards $5-\mathrm{HT}_{2 \mathrm{C}}$ receptor $\left(E_{\max }=16.6 \%\right.$ of the effect of $1 \mu \mathrm{mol} / \mathrm{L} 5$-HT) (Fig. 3B). While $5-\mathrm{HT}_{2 \mathrm{C}}$ receptor was activated $\left(E C_{50}=\right.$ $2075 \mathrm{nmol} / \mathrm{L}$ ), 5- $\mathrm{HT}_{2 \mathrm{~A} / 2 \mathrm{~B}}$ receptors remained inactive with the addition of up to $30,000 \mathrm{nmol} / \mathrm{L}$ $(+)$-isocorydine (5). Hence, (-)-crebanine (1)'s analog, $(+)$-isocorydine (5), showed different pharmacology characters towards $5-\mathrm{HT}_{2 \mathrm{C}}$ receptor.

\section{Identification of key interactions of (-)-crebanine with $5-\mathrm{HT}_{2 \mathrm{C}}$ receptor}

Binding mode of $(-)$-crebanine $(\mathbf{1})$ in $5-\mathrm{HT}_{2 \mathrm{C}}$ receptor model (built based on the crystal structure of $5 \mathrm{HT}_{2 \mathrm{~B}}$ receptor, PDB ID: 4IB4) is predicted by molecular docking (Fig. 4A). In the previous studies, the crystal structures of $5-\mathrm{HT}_{1 \mathrm{~B} / 2 \mathrm{~B}}$ in complex with ergotamine and 5-HT2B with lysergic acid diethylamide (LSD) revealed similar orthosteric ligand-binding cavities defined by residues from helixes III, V, VI, VII, and ECL2 (Wacker et al. 2013, 2017; Wang et al. 2013). The binding pocket is embedded deep in the 7TM core of the receptor and (-)-crebanine (1) partially overlaps with the ergoline rings of ergotamine bound to $5-\mathrm{HT}_{1 \mathrm{~B} / 2 \mathrm{~B}}$ receptor structures. Some key interactions are in common for $(-)$-crebanine and ergotamine: A salt bridge is formed between the positively charged nitrogen of (-)-crebanine (1) and the carboxylate of Asp $134^{3.32}$ (Venkatakrishnan et al. 2013) (Fig. 4B), which is fully conserved in 5-HT and other monoamine receptors. (-)-Crebanine (1) also forms $\pi-\pi$ interaction with a benzene ring to Phe327 6.51 , which resembles similar feature of ergotamine bound to $5-\mathrm{HT}_{1 \mathrm{~B}}$ and $5-\mathrm{HT}_{2 \mathrm{~B}}$ receptors. Due to the different shapes of aporphine and ergoline rings, (-)-crebanine also extends to space close to the entrance and forms hydrophobic interactions to Leu209 and Phe214 on ECL2. Hydrophobic interactions between (-)-crebanine (1) and Val135 $5^{3.33}$, Thr139 $9^{3.37}$, Gly218 $8^{5.42}$, Ala222 ${ }^{5.46}$, Trp324 $4^{6.48}$, Val354 ${ }^{7.39}$, and Tyr358 7.43 are also predicted. The different binding affinities and functions of (-)-crebanine (1) (antagonist) and $(+)$-isocorydine (5) (weak partial agonist) may due to the difference in chirality of the carbon atom or substitution groups in the aporphine scaffold. In this 

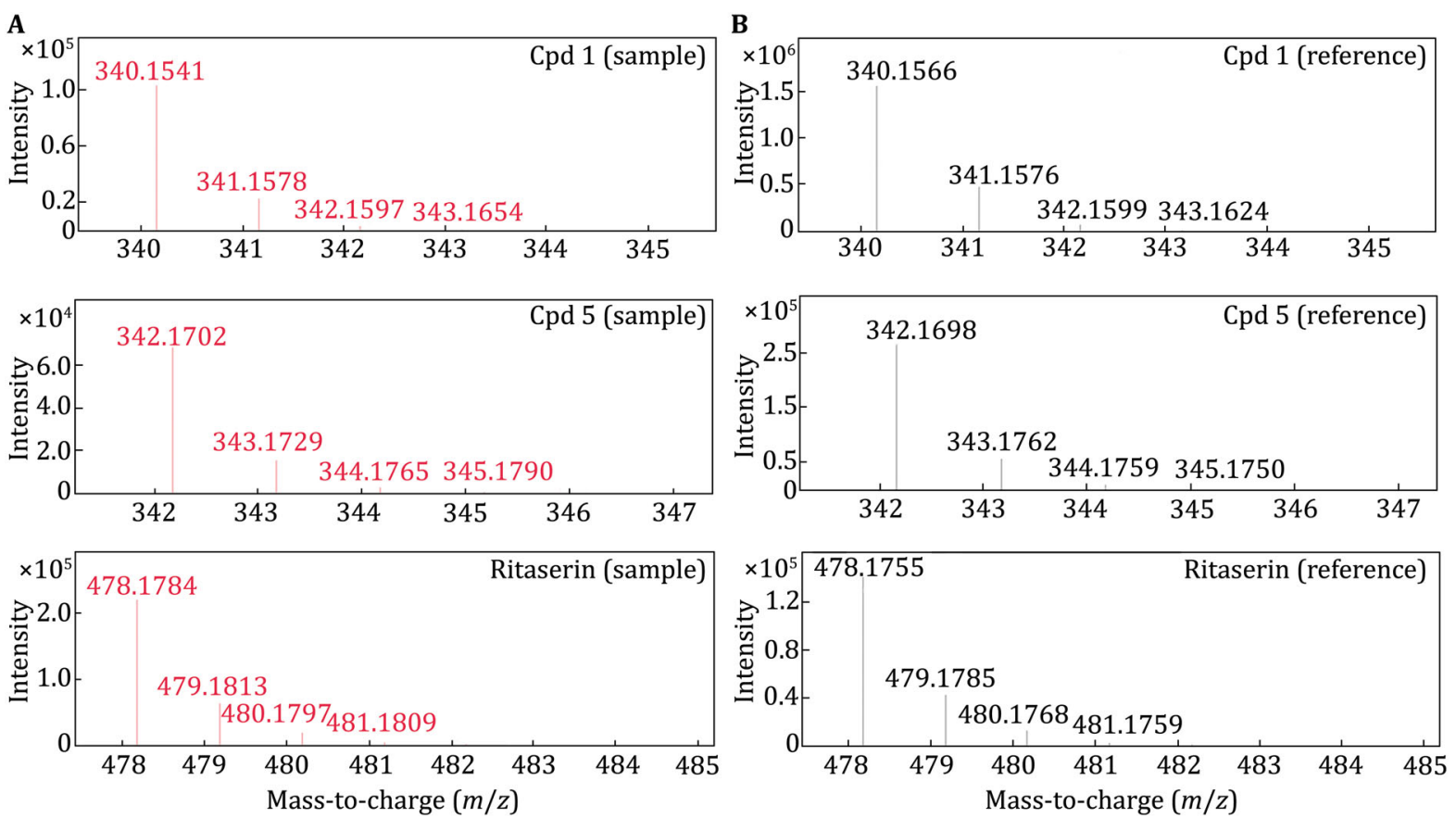

Fig. 2 Mass spectra of three compounds detected in the 5- $\mathrm{HT}_{2 \mathrm{C}}$ receptor incubation sample (A) and the corresponding reference (B). Matching accurate mass and retention time of each ligand with the reference data are required for confident structural assignment

A

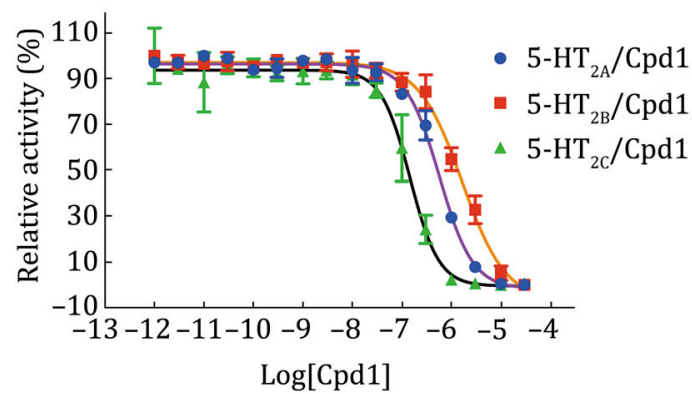

B

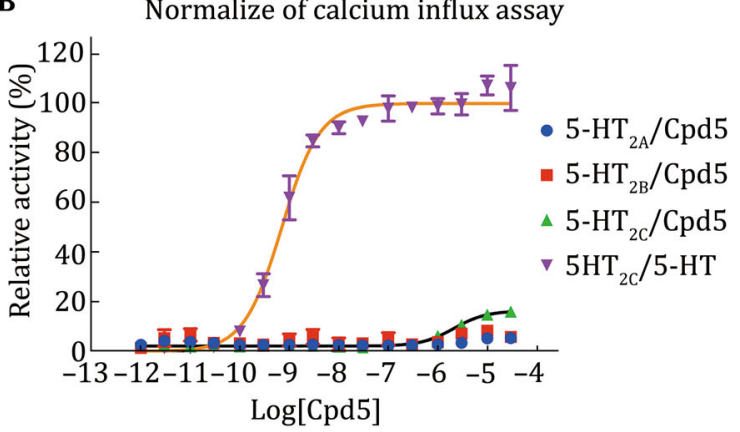

Fig. 3 Fluorescence-based calcium mobilization measurement of $5-\mathrm{HT}_{2 \mathrm{~A} / 2 \mathrm{~B} / 2 \mathrm{C}}$ mediated $\mathrm{G}_{\mathrm{q}}$ inhibition/activation by (-)-crebanine (1) and (+)-isocorydine (5), all in HEK 293 derived cells. A Normalized inhibition of compound $\mathbf{1}$ on human cloned 5-HT $2 \mathrm{~A} / 2 \mathrm{~B} / 2 \mathrm{C}$ receptormediated Gq signaling. $3 \mathrm{nmol} / \mathrm{L}$ of $5-\mathrm{HT}$ was used to induce initial activation. The $5-\mathrm{HT}_{2 \mathrm{C}}$ receptor shows the lowest $I C_{50}$ among the

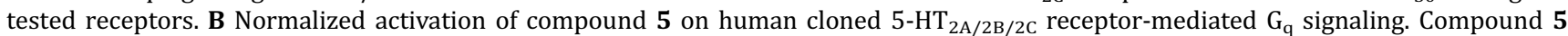
shows partial agonism against $5-\mathrm{HT}_{2 \mathrm{C}}$ receptor

predicted binding mode, the orientation of aporphine scaffold is the same to previously published docking results of dihydrofuroaporphine in $5 \mathrm{HT}_{1 \mathrm{~A}}$ (Yuan et al. 2016).

Based on the binding poses predicted by molecular docking, single-point mutations were designed to test their impact on ligand binding. Mutations of several residues include the highly conserved Asp $134^{3.32}$, which is known to cause $5-\mathrm{HT}_{1 \mathrm{~B}}$ or $5-\mathrm{HT}_{2 \mathrm{~B}}$ receptors to abolish the monoamine ligand binding as reported in the literature (Wang et al. 2013). In this study, residues forming hydrophobic interactions with the substitution groups on the aporphine scaffold of (-)-crebanine (1) were selected for mutation as well and they are Thr139 $9^{3.37}$, Gly218 ${ }^{5.42}$, Ala222 ${ }^{5.46}$, and Leu209 ${ }^{\text {ECL2 }}$. Effects of those mutations were tested with the CPM assay and the affinity MS assay (Table 2). In the affinity MS experiment, relative ligand-binding capacity (represented by binding \%) to different mutants and the wild-type receptor was compared. Among the six mutations tested, five of them reduced the binding of $(-)$-crebanine (1) by more than $40 \%$ relative to binding to the 

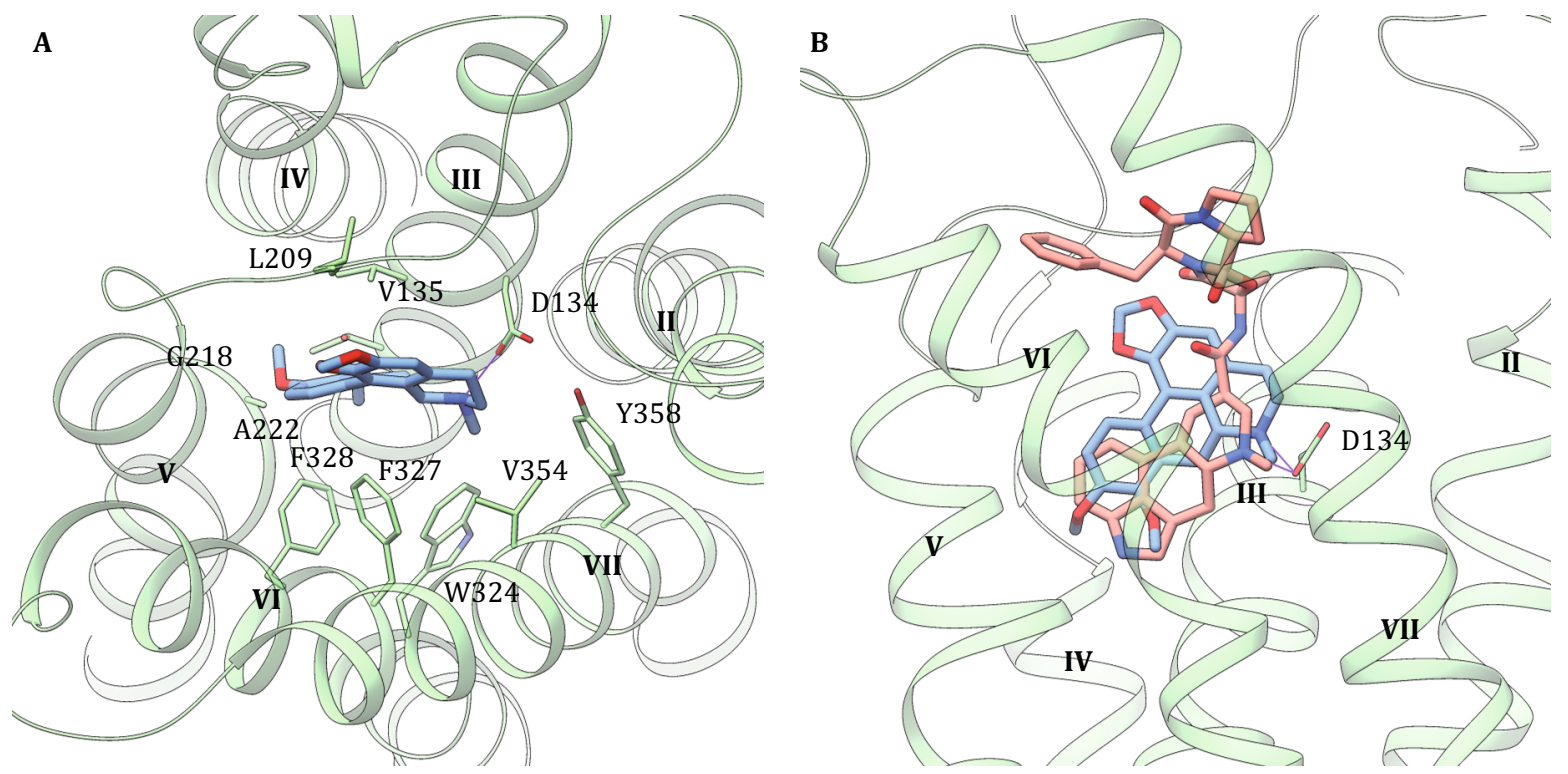

Fig. 4 Docked pose of (-)-crebanine in $5-\mathrm{HT}_{2 \mathrm{C}}$ model. A Ligand-receptor interactions. The key residues were labeled and showed in sticks. B Superposition with ergotamine in $5-\mathrm{HT}_{2 \mathrm{~B}}$ crystal structure

Table 2 Mutations validation on the ligand binding pocket using thermostability and affinity MS assay

\begin{tabular}{lll}
\hline Mutants & $\begin{array}{l}(-) \text {-Crebanine/CPM } \\
(n=2)\left({ }^{\circ} \mathrm{C}\right)\end{array}$ & $\begin{array}{l}(-) \text {-Crebanine/MS } \\
(n=2)^{\mathrm{a}}(\%)\end{array}$ \\
\hline $\mathrm{WT}$ & 59.93 & 27.57 \\
$\mathrm{G} 218^{5.42} \mathrm{~A}$ & 53.92 & 9.82 \\
$\mathrm{G} 218^{5.42} \mathrm{~S}$ & 53.24 & 6.04 \\
$\mathrm{~A} 222^{5.46} \mathrm{~V}$ & 59.55 & 25.84 \\
$\mathrm{~A} 222^{5.46} \mathrm{~F}$ & 55.70 & 15.87 \\
$\mathrm{~T} 139^{3.37} \mathrm{~A}$ & 54.63 & 14.64 \\
$\mathrm{~L} 209^{\text {ECL2 } \mathrm{F}}$ & 55.46 & 13.22 \\
\hline
\end{tabular}

${ }^{a}$ Relative ligand binding (\%) was calculated by the MS response of the ligand released from a specific mutant divided by the MS response of the total ligand present in the incubation sample

wild-type receptor, displaying the importance of hydrophobic interactions. Mutations Gly $218^{5.42} \mathrm{Ala} / \mathrm{Ser}$ impacted the binding of (-)-crebanine the most, causing the Tm values decreased over $6.0{ }^{\circ} \mathrm{C}$ and ligand-binding capacity reduced by over $60 \%$. These results fit the predicted compact interactions of (-)-crebanine (1) to Gly218 $8^{5.42}$. Thr $139^{3.37}$ is highly conserved residue in serotonin receptors, and Thr139 ${ }^{3.37}$ Ala led to the $\mathrm{Tm}$ value decrease and ligand potency lost. Leu $209^{\mathrm{ECL} 2} \mathrm{Phe}$ also has significant influence on the binding of (-)-crebanine (1), supporting our prediction that (-)-crebanine (1) forms hydrophobic interactions to residues on ECL2. Ala222 ${ }^{5.46} \mathrm{Phe}$ has a similar effect to Thr $139^{3.37}$ and Leu20 ${ }^{\mathrm{ECL} 2} \mathrm{Phe}$, while Ala222 ${ }^{5.46}$ Val is the only mutation having little effect on the thermostability of $(-)$-crebanine (1) bound $5-\mathrm{HT}_{2 \mathrm{C}}$ receptor ( $\mathrm{Tm}$ value decreased by $0.38{ }^{\circ} \mathrm{C}$ ) and ligand-binding capacity to the mutant inferred from the affinity MS assay. Different effects of mutations Ala $222^{5.46} \mathrm{Phe} / \mathrm{Val}$ show that there is some space in the pocket around this site, but too bulky side chain collides with (-)-crebanine (1).

\section{Crebanine attenuated the spontaneous synaptic current amplification induced by 5-HT}

5-HT receptors play important roles in central and peripheral nervous systems. Malfunctions of these receptors have been linked to many neural disorders such as depression and psychosis. The effect of (-)-crebanine on changes in 5-HT induced synaptic transmission was evaluated by electrophysiological recording of mouse brain slices (Jang et al. 2012). The spontaneous synaptic current (SPSC) of cortical pyramidal neurons was recorded in whole cell mode. The SPSC was amplified after 5-HT treatment at the concentration of $10 \mu \mathrm{mol} / \mathrm{L}$, while the effect of 5 -HT induced SPSC was significantly attenuated in the presence of $30 \mu \mathrm{mol} / \mathrm{L}(-)$-crebanine (1) incubation (Fig. 5).

\section{DISCUSSION}

Natural products contain a variety of components like alkaloids, peptides, lipids, glucosides, etc.. These diverse components are perfect candidates for serving as ligands to modulate the activity of $G$ protein-coupled receptors. Furthermore, a co-evolutional relationship 
A

Cpd $1+5-$ HT

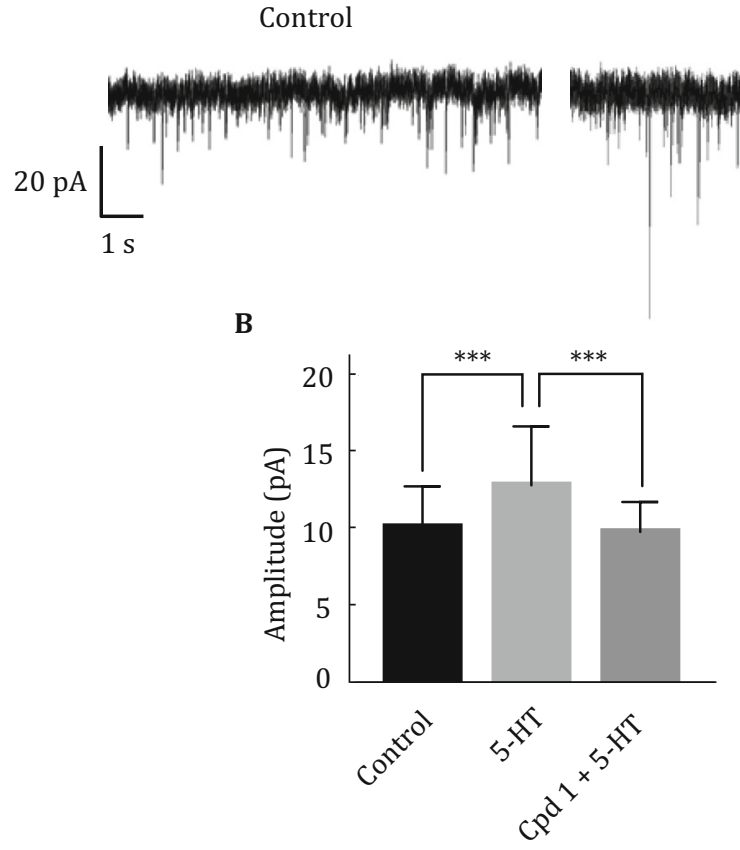

\section{anch}

B
5-HT

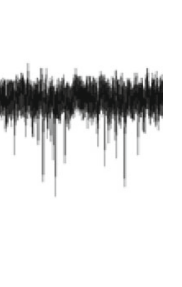

C

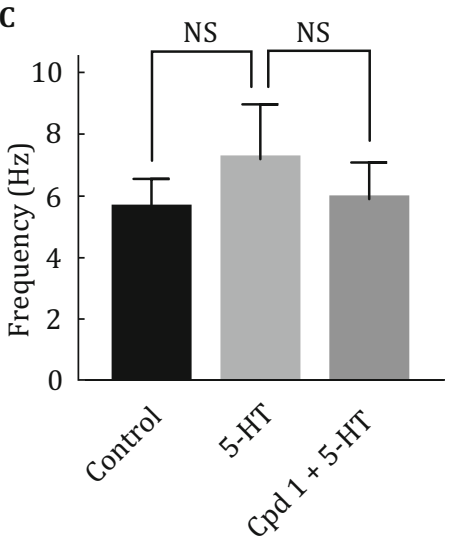

Fig. 5 Crebanine attenuated the SPSC amplification induced by 5-HT. A Representative traces of SPSC in control condition (left), and in response to 5-HT, with (middle) or without (right) (-)-crebanine. Amplitude histograms (B) and frequency histograms (C) of SPSC $(* * * p<0.001)$

has been noted between receptors and plants. This is supported by the fact that many endogenous ligands are related to phyto-compounds and there is a certain degree of overlap between the chemical spaces of endogenous ligands and components of natural products. Therefore, screening of focused libraries containing a sub-set of natural products that show chemical similarity to the known ligands of the target receptors has the potential to significantly increase the success rate of discovery of new ligands. Serotonin (5-HT) shares its scaffold with many alkaloids from plants. To identify novel ligands for $5-\mathrm{HT}_{2 \mathrm{C}}$ receptor, we selected and screened a focused natural products-based library enriched in alkaloids. A potential hit, (-)-crebanine (1), increased the $\mathrm{Tm}$ of $5-\mathrm{HT}_{2 \mathrm{C}}$ receptor by $9.25{ }^{\circ} \mathrm{C}$ during thermal denaturation assays. Ultrafiltration-based affinity mass spectrometry validated the interaction between (-)-crebanine (1) and $5-\mathrm{HT}_{2 \mathrm{C}}$ receptor, and estimated the affinity of the ligand for the receptor $\left(K_{\mathrm{d}} \sim 0.34 \mu \mathrm{mol} / \mathrm{L}\right)$. Using cell-based calcium influx assay, we identified (-)-crebanine (1) to be an antagonist of $5-\mathrm{HT}_{2 \mathrm{C}}$ receptor. Furthermore, we predict its binding pose in $5-\mathrm{HT}_{2 \mathrm{C}}$ receptor by molecular docking and several key interactions of the ligand with the protein are proposed. The subsequent mutagenesis and binding experiments confirmed the predicted binding pose. In order to find out if (-)-crebanine (1) plays a role in modulating the function of 5-HT receptors at tissue level, we recorded the electrical potential across the membrane of neurons from mice brain slices. (-)-Crebanine (1) inhibited the excitability caused by 5-HT in the brain slices, implying that (-)-crebanine (1) is effective in inhibiting the activity of 5-HT receptors and counteracting the excitatory role of $5-\mathrm{HT}$ in the central nervous system of mice.

In summary, we have identified (-)-crebanine (1) as an antagonist for $5-\mathrm{HT}_{2 \mathrm{~A} / 2 \mathrm{~B} / 2 \mathrm{C}}$ receptors. The $I C_{50}$ value of the compound was the lowest $(149 \mathrm{nmol} / \mathrm{L})$ for $5-\mathrm{HT}_{2 \mathrm{C}}$ receptor, suggesting some specificity in targeting the type of receptor. Structure-guided optimization of the crebanine scaffold is likely to further increase the receptor specificity. This is important because inhibition of $5-\mathrm{HT}_{2 \mathrm{C}}$ receptor activity has been shown to cure depression, schizophrenia and drug addiction. Results of our studies provide a framework for developing $5-\mathrm{HT}_{2 \mathrm{C}}$ receptor-specific antipsychotic drug. We show that natural products can be a viable source of novel ligands for $5-\mathrm{HT}_{2 \mathrm{C}}$ receptor. A comprehensive approach to screen and characterize novel ligands of GPCRs from the natural product library is also described in this study. We believe that the experimental protocols and analytical methods are general and could be used to facilitate biochemical and pharmacological studies for discovery of novel ligands targeting other GPCRs. 


\section{EXPERIMENTAL SECTION}

\section{Compounds library preparation}

(-)-Crebanine (compound 1) and (-)-dicentrine (compound 2) were isolated from A. scholaris as previously described (Shang et al. 2010). Compounds (3-5) were purchased from Herbpurify Co., Ltd., Chengdu, China. Briefly, organic compounds from dried and powdered leaves of A. scholaris were extracted with ethanol and the solvent was evaporated under vacuum to obtain an extract. The extract was dissolved in 1\% HCL and the constituents of the solution were considered as the alkaloid fraction. The solution was basified using ammonia water and extracted with ethyl acetate. The alkaloid extract was subjected to silica gel chromatography and eluted with chloroform-methanol (30:1-1:1) mixture in six fractions (I-VI). (-)-Crebanine and $(-)$-dicentrine were purified from fraction IV after column chromatography over silica gel (chloroformacetone) and reverse phase $\mathrm{RP}_{18}$ (methanol-water). The structures were validated by ${ }^{1} \mathrm{H}$ NMR spectrum analysis.

$(-)$-Crebanine (1) was obtained as colorless powder. ${ }^{1} \mathrm{H}$ NMR $\left(\mathrm{CDCl}_{3}, 500 \mathrm{MHz}\right): \delta 7.80(1 \mathrm{H}, \mathrm{d}, J=8.5 \mathrm{~Hz}$, $\mathrm{H}-11), 6.88(1 \mathrm{H}, \mathrm{d}, J=8.5 \mathrm{~Hz}, \mathrm{H}-10), 6.53(1 \mathrm{H}, \mathrm{s}, \mathrm{H}-3)$, $6.06\left(1 \mathrm{H}, \quad \mathrm{d}, J=1.4 \mathrm{~Hz},-\mathrm{OCH}_{2} \mathrm{O}-\right), 5.91(1 \mathrm{H}, \mathrm{d}$, $\left.J=1.4 \mathrm{~Hz},-\mathrm{OCH}_{2} \mathrm{O}-\right), 3.90\left(3 \mathrm{H}, \mathrm{s},-\mathrm{OCH}_{3}\right), 3.81(3 \mathrm{H}, \mathrm{s}$, $\left.-\mathrm{OCH}_{3}\right), 3.67(1 \mathrm{H}, \mathrm{dd}, J=14.0,4.0 \mathrm{~Hz}, \mathrm{H}-7), 3.12(1 \mathrm{H}, \mathrm{m}$, $\mathrm{H}-6 \mathrm{a}), 3.05(2 \mathrm{H}, \mathrm{m}, \mathrm{H}-4), 2.63(1 \mathrm{H}, \mathrm{dd}, J=16.0,3.0 \mathrm{~Hz}$, $\mathrm{H}-5), 2.59\left(3 \mathrm{H}, \mathrm{s},-\mathrm{NCH}_{3}\right), 2.52(1 \mathrm{H}, \mathrm{dd}, J=16.0,3.0 \mathrm{~Hz}$, $\mathrm{H}-5), 2.30(1 \mathrm{H}, \mathrm{dd}, J=14.5,14.0 \mathrm{~Hz}, \mathrm{H}-7)$ (Bartley et al. 1994).

(-)-Dicentrine (2) was obtained as colorless powder. ${ }^{1} \mathrm{H}$ NMR $\left(\mathrm{CDCl}_{3}, 500 \mathrm{MHz}\right): \delta 7.67(1 \mathrm{H}, \mathrm{s}, \mathrm{H}-11), 6.78$ $(1 \mathrm{H}, \mathrm{s}, \mathrm{H}-10), 6.52(1 \mathrm{H}, \mathrm{s}, \mathrm{H}-3), 6.08(1 \mathrm{H}, \mathrm{d}, J=1.4 \mathrm{~Hz}$, $-\mathrm{OCH}_{2} \mathrm{O}-$ ), $5.93\left(1 \mathrm{H}, \mathrm{d}, J=1.4 \mathrm{~Hz},-\mathrm{OCH}_{2} \mathrm{O}-\right), 3.92(3 \mathrm{H}, \mathrm{s}$, $\left.-\mathrm{OCH}_{3}\right), 3.92\left(3 \mathrm{H}, \mathrm{s},-\mathrm{OCH}_{3}\right), 3.09(1 \mathrm{H}, \mathrm{dd}, J=14.0$, $4.5 \mathrm{~Hz}, \mathrm{H}-7), 3.12$ (1H, m, H-6a), 3.05 (2H, m, H-4), 2.67 $(1 \mathrm{H}, \mathrm{dd}, J=16.0,3.0 \mathrm{~Hz}, \mathrm{H}-5), 2.56\left(3 \mathrm{H}, \mathrm{s},-\mathrm{NCH}_{3}\right), 2.62$ $(1 \mathrm{H}, \mathrm{dd}, J=16.0,3.0 \mathrm{~Hz}, \mathrm{H}-5), 2.53(1 \mathrm{H}, \mathrm{dd}, J=14.5$, $14.0 \mathrm{~Hz}, \mathrm{H}-7$ ) (Shang et al. 2010).

$(+)$-Magnoflorine (3) was obtained as brown powder. ${ }^{1} \mathrm{H}$ NMR (DMSO- $\left.d_{6}, 400 \mathrm{MHz}\right): \delta 6.60(1 \mathrm{H}, \mathrm{d}, J=8.0 \mathrm{~Hz}$, $\mathrm{H}-9), 6.36(1 \mathrm{H}, \mathrm{d}, J=8.0 \mathrm{~Hz}, \mathrm{H}-8), 6.51(1 \mathrm{H}, \mathrm{s}, \mathrm{H}-3)$, $4.37(1 \mathrm{H}, \mathrm{d}, J=11.5 \mathrm{~Hz}, \mathrm{H}-6 \mathrm{a}), 3.69\left(3 \mathrm{H}, \mathrm{s},-\mathrm{OCH}_{3}\right), 3.66$ $\left(3 \mathrm{H}, \mathrm{s},-\mathrm{OCH}_{3}\right), 3.67(1 \mathrm{H}, \mathrm{m}$, overlap, $\mathrm{H}-5), 3.60(1 \mathrm{H}, \mathrm{m}$, $\mathrm{H}-5), 3.33\left(3 \mathrm{H}, \mathrm{H},-\mathrm{NCH}_{3}\right), 3.12(1 \mathrm{H}, \mathrm{dd}, J=14.0$, $13.0 \mathrm{~Hz}, \mathrm{H}-4), 3.11(1 \mathrm{H}, \mathrm{dd}, J=13.0,3.5 \mathrm{~Hz}, \mathrm{H}-7), 2.90$ $\left(3 \mathrm{H}, \mathrm{s},-\mathrm{NCH}_{3}\right), 2.82(1 \mathrm{H}, \mathrm{dd}, J=14.0,3.0 \mathrm{~Hz}, \mathrm{H}-5), 2.61$ $(1 \mathrm{H}, \mathrm{dd}, J=14.5,13.0 \mathrm{~Hz}, \mathrm{H}-7)$ (Yin et al. 2016).

Didehydroglaucine (4) was obtained as light greenish powder. ${ }^{1} \mathrm{H}$ NMR (DMSO- $d_{6}, 400 \mathrm{MHz}$ ): $\delta 8.91(1 \mathrm{H}, \mathrm{s}$, H-11), 7.18 (1H, s, H-8), 7.18 (1H, s, H-7), $6.61(1 \mathrm{H}, \mathrm{s}$,
$\mathrm{H}-3), 3.94\left(3 \mathrm{H}, \mathrm{s},-\mathrm{OCH}_{3}\right), 3.87\left(3 \mathrm{H}, \mathrm{s},-\mathrm{OCH}_{3}\right), 3.86(3 \mathrm{H}$, $\left.\mathrm{s},-\mathrm{OCH}_{3}\right), 3.81\left(3 \mathrm{H}, \mathrm{s},-\mathrm{OCH}_{3}\right), 3.29(1 \mathrm{H}, \mathrm{t}, J=6.5 \mathrm{~Hz}$, $\mathrm{H}-4), 3.20(1 \mathrm{H}, \mathrm{t}, J=6.5 \mathrm{~Hz}, \mathrm{H}-7), 2.99(3 \mathrm{H}, \mathrm{s}$, $-\mathrm{NCH}_{3}$ ) (Xu et al. 2002).

$(+)$-Isocorydine (5) was obtained as colorless crystal. ${ }^{1} \mathrm{H}$ NMR (DMSO- $d_{6}, 400 \mathrm{MHz}$ ): $\delta 8.64(1 \mathrm{H}, \mathrm{s},-\mathrm{OH}), 6.98$ $(1 \mathrm{H}, \mathrm{s}, \mathrm{H}-3), 6.97(1 \mathrm{H}, \mathrm{d}, J=8.0 \mathrm{~Hz}, \mathrm{H}-8), 6.88(1 \mathrm{H}, \mathrm{d}$, $J=8.0 \mathrm{~Hz}, \mathrm{H}-9), 4.06(1 \mathrm{H}, \mathrm{m}, \mathrm{H}-6 \mathrm{a}), 3.86\left(3 \mathrm{H}, \mathrm{s},-\mathrm{OCH}_{3}\right)$, $3.80\left(3 \mathrm{H}, \mathrm{s},-\mathrm{OCH}_{3}\right), 3.65\left(3 \mathrm{H}, \mathrm{s},-\mathrm{OCH}_{3}\right), 3.36(1 \mathrm{H}, \mathrm{m}$, $\mathrm{H}-7), 3.35$ (1H, m, H-5), $3.05(2 \mathrm{H}, \mathrm{m}, \mathrm{H}-4), 2.99(1 \mathrm{H}, \mathrm{m}$, $\mathrm{H}-5), 2.98(1 \mathrm{H}, \mathrm{m}, \mathrm{H}-7), 2.59\left(3 \mathrm{H}, \mathrm{s}\right.$, overlap, $\left.-\mathrm{NCH}_{3}\right)$ (Zhong et al. 2015).

\section{Cloning}

The $\Delta \mathrm{N}-5-\mathrm{HT}_{2 \mathrm{C}}$-BRIL- $\Delta \mathrm{C}$ DNA was codon optimized, synthesized by DNA2.0 and subcloned into a modified pFastBac1 vector (Invitrogen). The construct had the following features: (1) Residues of the third intracellular loop of the wild-type human $5-\mathrm{HT}_{2 \mathrm{C}}$ receptor were replaced with Ala1-Leu106 of BRIL; (2) N-terminal residues before and including the glycosylation site and C-terminal residues after the helix 8 of $5-\mathrm{HT}_{2 \mathrm{C}}$ receptor were truncated. An apocytochrome $b_{562}$ RIL (BRIL) gene from E. coli, with M7 W, H102I, and R106L mutations is referred to as BRIL.

The vector designated as pFastBac1-830220 contained an expression cassette with a haemagglutinin (HA) signal sequence followed by a FLAG tag at the $\mathrm{N}$-terminus, and a PreScission protease site followed by a $10 \times$ His tag at the C-terminus (Lv et al. 2016).

\section{Virus generation and expression}

High-titer recombinant baculovirus $\left(>10^{9}\right.$ viral particles per $\mathrm{ml}$ ) was obtained using the Bac-to-Bac Baculovirus Expression System (Invitrogen). Recombinant baculovirus was generated by transfecting 5-10 $\mu \mathrm{g}$ of recombinant bacmid into $2.5 \mathrm{ml}$ Spodoptera frugiperda (Sf9) cells at a density of $10^{6}$ cells per ml using $5 \mu \mathrm{l}$ of FuGENE HD Transfection Reagent (Promega) and Transfection Medium (Expression Systems). After 4 days of shaking at $27{ }^{\circ} \mathrm{C}$, P0 viral stock with $\sim 10^{9}$ virus particles per $\mathrm{ml}$ was harvested and used to generate high-titer baculovirus stock. Viral titers were determined by flow-cytometric analysis of cells stained with gp64-PE antibody (Expression Systems) (Hanson et al. 2007). Expression of the $5-\mathrm{HT}_{2 \mathrm{C}}$ receptor was carried out by infection of $S f 9$ cells at a cell density of $2-3 \times 10^{6}$ cells $/ \mathrm{ml}$ with P1 virus stock at multiplicity of infection (MOI) of five. Cells were harvested by centrifugation at $48 \mathrm{~h}$ post-infection and stored at $-80{ }^{\circ} \mathrm{C}$ until further use. 


\section{Membrane purification}

Insect cell membranes were disrupted by thawing frozen cell pellets in a hypotonic buffer containing $10 \mathrm{mmol} / \mathrm{L}$ HEPES, pH 7.5, $10 \mathrm{mmol} / \mathrm{L} \quad \mathrm{MgCl}_{2}$, $20 \mathrm{mmol} / \mathrm{L} \mathrm{KCl}$ and EDTA-free complete protease inhibitor cocktail tablets (Roche). Extensive washing of the isolated raw membranes was performed by repeated centrifugation in the same hypotonic buffer (two times), and then in a high osmotic buffer containing $1.0 \mathrm{~mol} / \mathrm{L}$ $\mathrm{NaCl}, 10 \mathrm{mmol} / \mathrm{L}$ HEPES, pH 7.5, $10 \mathrm{mmol} / \mathrm{L} \mathrm{MgCl}_{2}$, $20 \mathrm{mmol} / \mathrm{L} \mathrm{KCl}$ and EDTA-free complete protease inhibitor cocktail tablets (three times), to remove soluble and membrane-associated proteins. Purified membranes were directly flash-frozen in liquid nitrogen and stored at $-80{ }^{\circ} \mathrm{C}$ until further use.

\section{Protein purification}

Purified membranes were resuspended in buffer containing $10 \mathrm{mmol} / \mathrm{L}$ HEPES, $\mathrm{pH} 7.5,10 \mathrm{mmol} / \mathrm{L} \mathrm{MgCl}_{2}$, $20 \mathrm{mmol} / \mathrm{L} \mathrm{KCl}, 150 \mathrm{mmol} / \mathrm{L} \mathrm{NaCl}$, and EDTA-free complete protease inhibitor cocktail tablets (Roche). Prior to solubilization, membranes were equilibrated at $4{ }^{\circ} \mathrm{C}$ and incubated for $30 \mathrm{~min}$ in the presence of $2 \mathrm{mg} / \mathrm{mL}$ iodoacetamide (Sigma). Membranes were then solubilized in $50 \mathrm{mmol} / \mathrm{L}$ HEPES, pH 7.5, $150 \mathrm{mmol} / \mathrm{L} \mathrm{NaCl}, 1 \%(w / v)$ n-dodecyl- $\beta$-D-maltopyranoside (DDM, Anatrace), $0.2 \% \quad(w / v)$ cholesteryl hemisuccinate (CHS, Sigma) and EDTA-free complete protease inhibitor cocktail tablets (Roche) for $2 \mathrm{~h}$ at $4{ }^{\circ} \mathrm{C}$. Unsolubilized material was removed by centrifugation at $35,000 \mathrm{r} / \mathrm{min}$ for $30 \mathrm{~min}$, and buffered imidazole and $\mathrm{NaCl}$ were added to the supernatant to adjust concentrations to 20 and $800 \mathrm{mmol} / \mathrm{L}$, respectively. Proteins were bound to TALON IMAC resin (Clontech) overnight at $4{ }^{\circ} \mathrm{C}$. The resin was then washed with 10 column volumes (cv) of Wash Buffer I (50 mmol/L HEPES, pH 7.5, $800 \mathrm{mmol} / \mathrm{L} \mathrm{NaCl}, 0.1 \%$ $(w / v)$ DDM, $0.02 \%(w / v)$ CHS, $20 \mathrm{mmol} / \mathrm{L}$ imidazole, $10 \%(\mathrm{v} / \mathrm{v})$ glycerol), followed by $5 \mathrm{cv}$ of Wash Buffer II (50 mmol/L HEPES, pH 7.5, $150 \mathrm{mmol} / \mathrm{L} \mathrm{NaCl}, 0.05 \%$ $(w / v)$ DDM, $0.01 \%(w / v)$ CHS, 10\% ( $v / v)$ glycerol). Proteins were eluted in $5 \mathrm{cv}$ of Wash Buffer II $+250 \mathrm{mmol} / \mathrm{L}$ imidazole. Protein purity and monodispersity were tested by SDS-PAGE and analytical size-exclusion chromatography (aSEC).

\section{Thermal stability assay}

Purified 5- $\mathrm{HT}_{2 \mathrm{C}}$ receptor protein was thoroughly mixed with CPM fluorescent dyes. Protein solution containing the fluorescent dyes and compounds was dispensed into 0.2-ml tubes using a pipetting workstation. The tubes were incubated at $4{ }^{\circ} \mathrm{C}$ for $1 \mathrm{~h}$ prior to thermal denaturation. As the temperature was ramped from 25 to $95^{\circ} \mathrm{C}$, the protein began to unfold, exposing the cysteine residues that interact with the dye. Fluorescence signals, wavelength $387 \mathrm{~nm}$ (excitation) and $463 \mathrm{~nm}$ (emission), were monitored (Alexandrov et al. 2008). Analysis of 72 different samples was performed in parallel. The thermal denaturation of the samples was evaluated using the scatter plot curve, where the horizontal coordinates represented temperature and the vertical coordinates indicated normalized fluorescence intensity recorded for a particular temperature. Tm was obtained by fitting the data with a Boltzmann sigmoidal function using Prism (GraphPad Software).

\section{Ligand-binding validation by affinity mass spectrometry analysis}

The purified apo $5-\mathrm{HT}_{2 \mathrm{C}}$ receptor protein was incubated with each pure ligand (compounds $\mathbf{1}, \mathbf{5}$ or ritanserin) at a final concentration of $500 \mathrm{nmol} / \mathrm{L}$ (protein) and $250 \mathrm{nmol} / \mathrm{L}$ (ligand) at $4{ }^{\circ} \mathrm{C}$ for $60 \mathrm{~min}$. Individual $5-\mathrm{HT}_{2 \mathrm{C}}$ mutants were incubated with compound $\mathbf{1}$ under the same condition. Then, the incubated sample $(\sim 1 \mu \mathrm{g})$ was filtered through $50 \mathrm{kDa}$ MW cutoff ultrafiltration membrane (Sartorius, Germany) by centrifugation at $13,000 \mathrm{~g}$ for $10 \mathrm{~min}$ at $4{ }^{\circ} \mathrm{C}$ in the buffer containing $150 \mathrm{mmol} / \mathrm{L}$ ammonium acetate, $0.02 \%(\mathrm{w} /$ $v)$ DDM and $0.004 \%(w / v)$ CHS. Buffer exchange was repeated once. The protein complexes retained on the ultrafiltration membrane were transferred to a new centrifugal tube. The ligand was dissociated from the complexes with $90 \%$ methanol and separated from the denatured protein by centrifugation at $13,000 \mathrm{~g}$ for $20 \mathrm{~min}$ at $25{ }^{\circ} \mathrm{C}$. Another purified GPCR protein (hydroxycarboxylic acid receptor 2) underwent the same process to serve as a negative control. The supernatant was dried out in speed vacuum, reconstituted in $50 \%$ methanol, diluted by tenfold prior to LC-MS analysis using Agilent 6530 TOF equipped with an Agilent 1260 HPLC system. The compound was eluted with $85 \%$ acetonitrile $/ 0.1 \%$ formic acid from Eclipse Plus C18 column $(2.1 \mathrm{~mm} \times 100 \mathrm{~mm}, 3.5 \mu \mathrm{m}$, Agilent, USA $)$ at a flow rate of $0.4 \mathrm{ml} / \mathrm{min}$. Full-scan mass spectra were acquired in the range of $100-1000 \mathrm{~m} / \mathrm{z}$ on Agilent 6530 TOF with ESI source settings: voltage $3000 \mathrm{~V}$, gas temperature $350{ }^{\circ} \mathrm{C}$, fragmentor $150 \mathrm{~V}$.

Four experimental replicates were prepared for each pair of the test ligand and the negative control. LC-MS chromatograms for specific ligands were extracted using MassHunter software (Agilent, USA) based on the accurate mass measurement with a tolerance of $15 \mathrm{ppm}$ 
and also matching RT of the reference compound. MS responses are represented by the peak heights of the corresponding extracted ion chromatograms. S/C ratios refer to the ratio of MS response of a specific ligand detected in the $5-\mathrm{HT}_{2 \mathrm{C}}$ incubation sample versus the control. A single-point $K_{\mathrm{d}}$ calculation method established earlier for binding evaluation of pure ligands or simple ligand mixtures was then employed to estimate the affinity of each ligand to the receptor (Qin et al. 2015). Relative ligand-binding capacity (represented by binding \%) to different mutants was calculated by the MS response of the ligand released from a specific mutant divided by the MS response of the total ligand present in the incubation sample.

\section{$\mathrm{Ca}^{2+}$ mobilization assay}

HEK 293T cells stably transfected with $5-\mathrm{HT}_{2 \mathrm{~A} / 2 \mathrm{~B} / 2 \mathrm{C}}$ receptor were seeded in 384-well plates at a density of 15,000 cells/well in DMEM containing 1\% dialyzed FBS $8 \mathrm{~h}$ before the calcium flux assay. After removing medium, cells were then incubated $(20 \mu \mathrm{l} /$ well $)$ for $1 \mathrm{~h}$ at $37{ }^{\circ} \mathrm{C}$ with Fluo-4 Direct dye (Invitrogen) reconstituted in FLIPR buffer $(1 \times$ HBSS, $2.5 \mathrm{mmol} / \mathrm{L}$ probenecid, and $20 \mathrm{mmol} / \mathrm{L}$ HEPES, pH 7.4). After the dye loaded, cells were placed in a FLIPR ${ }^{\text {TETRA }}$ fluorescence imaging plate reader (Molecular Devices); drug dilutions, prepared at $3 \times$ final concentration in FLIPR buffer and aliquotted into 384-well plates, were also added to the FLIPR ${ }^{\text {TETRA }}$. The fluidics module and plate reader of the FLIPR ${ }^{\text {TETRA }}$ were programmed to read baseline fluorescence for $10 \mathrm{~s}(1 \mathrm{read} / \mathrm{s})$, then to add $10 \mu \mathrm{l}$ of drug/well and to read for $6 \mathrm{~min}(1 \mathrm{read} / \mathrm{s})$. Fluorescence in each well was normalized to the average of the first 10 reads (i.e., baseline fluorescence). Then, the maximum-fold increase, which occurred within $60 \mathrm{~s}$ after drug addition, over baseline fluorescence elicited by vehicle or drug was determined. For positive allosteric modulator and antagonist candidates test, 5 -HT EC20 (0.1 nmol/L) and EC80 (3 nmol/L) were used, respectively, to activate receptor.

\section{Modeling of 5-HT $2 \mathrm{C}$ in complex with crebanine}

Modeling of receptor-ligand complexes was carried out with Schrodinger Suite 2015-4. Homology model of $5-\mathrm{HT}_{2 \mathrm{C}}$ receptor was built based on the crystal structure of 5- $\mathrm{HT}_{2 \mathrm{~B}}$ (PDB entry: 4IB4) using the Advanced Homology Modeling tool. Processing of the protein structure was performed with the Protein Preparation Wizard. 3D structures of the compounds were first generated using the LigPrep tool, then optimized by quantum mechanics in B3LYP/6-31G** level using
Jaguar 9.0. The complex structures were generated in three steps: (1) Molecular docking of the compounds into $5-\mathrm{HT}_{2 \mathrm{C}}$ homology model using Glide 6.9; (2) Structural refinements allowing movement of the compounds and protein atoms within $5 \AA$ using Prime 4.2; (3) Re-scoring the binding modes of compounds in the receptors by the extra-precision score using Glide 6.9.

\section{Brain slicing preparation}

Cortical slices from ICR mouse of both genders (15-21 days) were prepared for electrophysiological recording. In brief, the animals were decapitated and brains were placed in cold sucrose artificial cerebrospinal fluid (sucrose-ASCF, in mmol/L: sucrose 213, KCl 2.5, $\mathrm{NaH}_{2} \mathrm{PO}_{4}$ 1.25, $\mathrm{NaHCO}_{3} 26, D$-glucose 10, $\mathrm{MgSO}_{4} 2, \mathrm{CaCl}_{2} 2, \mathrm{pH} 7.4,0-4{ }^{\circ} \mathrm{C}$, saturated with $95 \% \mathrm{O}_{2}$ and $5 \% \mathrm{CO}_{2}$ ). The brains were cut into 280 or $300 \mu \mathrm{m}$ slices with a vibratome (Leica VT1200S, Germany); slices were then incubated with ACSF (in mmol/L: $\mathrm{NaCl}$ 126, KCl 2.5, $\mathrm{NaH}_{2} \mathrm{PO}_{4} 1.25, \mathrm{NaHCO}_{3} 26, D$-glucose 25, $\mathrm{MgSO}_{4} 2, \mathrm{CaCl}_{2} 2$, pH 7.4, saturated with $95 \% \mathrm{O}_{2}$ and $5 \% \mathrm{CO}_{2}$ ) at room temperature for $1 \mathrm{~h}$.

\section{Electrophysiological recordings}

A whole-cell patch clamp technique was used. One brain slice was transferred into the recording chamber, continually perfused with oxygenated ACSF and viewed under a DIC microscope $(60 \times$ water immersion lens, Olympus, Japan). Activity of cortical pyramidal neurons was recorded using an amplifier (HEKA EPC 10 USB, Germany) in the voltage clamp mode. The electrode puller (Sutter P-1000, USA) was used to make electrodes with the resistance at 10-13 M $\Omega$ when filled with the pipette solution (in mmol/L: potassium gluconate 140, $\mathrm{KCl} 3, \mathrm{MgCl}_{2}$ 2, HEPES 10, EGTA 0.2, $\mathrm{Na}_{2} \mathrm{ATP} 2$, pH 7.25). Drug treatments were performed by switching the perfusion solution with different drugs (5-HT, compound $\mathbf{1}$, compound $\mathbf{1}$ and 5-HT). To evaluate the effect of 1 against 5-HT, the brain slices were pretreated by 1 for $15-20 \mathrm{~min}$.

\author{
Abbreviations \\ 5-HT 5-hydroxytryptamine \\ CNS Central nervous system \\ CPM The thiol-specific fluorochrome N-[4-(7- \\ diethylamino- 4-methyl-3-coumarinyl) phenyl] \\ maleimide \\ GPCR G protein-coupled receptor \\ ICL3 Intracellular loop 3 \\ LSD Lysergic acid diethylamide
}


MS Mass spectrometry

Sf9 Spodoptera frugiperda (an insect cell line)

SPSC Spontaneous synaptic current

Acknowledgements This work was funded by the National Nature Science Foundation of China (31330019), the Shanghai Municipal Government, ShanghaiTech University and the Institute of Molecular and Clinical Medicine, Kunming Medical University. We thank the cloning, cell expression, protein purification, functional assay and bioImaging core facilities of iHuman Institute for their support. We thank Xiping Huang of Bryan Roth group in the University of North Carolina at Chapel Hill for the help on cellbased assay experiment. We thank Tian Hua, Houchao Tao, Dongsheng Liu, for the helpful discussions.

\section{Compliance with Ethical Standards}

Conflict of interest Yao Peng, Simeng Zhao, Yiran Wu, Haijie Cao, Yueming $\mathrm{Xu}$, Xiaoyan Liu, Wenqing Shui, Jianjun Cheng, Suwen Zhao, Ling Shen, Raymond C. Stevens, Jun Ma, Ronald J. Quinn, Guisheng Zhong, and Zhi-Jie Liu declare that they have no conflict of interest.

Human and animal rights and informed consent All institutional and national guidelines for the care and use of laboratory animals were followed.

Open Access This article is distributed under the terms of the Creative Commons Attribution 4.0 International License (http:// creativecommons.org/licenses/by/4.0/), which permits unrestricted use, distribution, and reproduction in any medium, provided you give appropriate credit to the original author(s) and the source, provide a link to the Creative Commons license, and indicate if changes were made.

\section{References}

Ahn K (2016) Worldwide trend of botanical drug and strategies for developing global drugs. BMB Rep 50(3):111-116

Alexandrov AI, Mileni M, Chien EY, Hanson MA, Stevens RC (2008) Microscale fluorescent thermal stability assay for membrane proteins. Structure 16:351-359

All natural (2007) Nat Chem Biol 3: 351

Bartley JP, Baker LT, Carvalho CF (1994) Alkaloids of Stephania bancroftii. Phytochemistry 36:1327-1331

Besnard J, Ruda GF, Setola V, Abecassis K, Rodriguiz RM, Huang XP, Norval S, Sassano MF, Shin AI, Webster LA, Simeons FR, Stojanovski L, Prat A, Seidah NG, Constam DB, Bickerton GR, Read KD, Wetsel WC, Gilbert IH, Roth BL, Hopkins AL (2012) Automated design of ligands to polypharmacological profiles. Nature 492:215-220

Chen X, Qin S, Chen S, Li J, Li L, Wang Z, Wang Q Lin J, Yang C, Shui W (2015) A ligand-observed mass spectrometry approach integrated into the fragment based lead discovery pipeline. Sci Rep 5:8361

Cheng J, McCorvy JD, Giguere PM, Zhu H, Kenakin T, Roth BL, Kozikowski AP (2016) Design and discovery of functionally selective serotonin 2C (5-HT2C) receptor agonists. J Med Chem 59:9866-9880
Connolly HM, Crary JL, McGoon MD, Hensrud DD, Edwards BS, Edwards WD, Schaff HV (1997) Valvular heart disease associated with fenfluramine-phentermine. $\mathrm{N}$ Engl J Med 337:581-588

Englisch S, Jung HS, Lewien A, Becker A, Nowak U, Braun H, Thiem J, Eisenacher S, Meyer-Lindenberg A, Zink M (2016) Agomelatine for the treatment of major depressive episodes in schizophrenia-spectrum disorders: an open-prospective proof-of-concept study. J Clin Psychopharmacol 36(6):597-607

Halford JC, Harrold JA (2012) 5-HT(2C) receptor agonists and the control of appetite. Handb Exp Pharmacol. https://doi.org/ 10.1007/978-3-642-24716-3_16

Hannon J, Hoyer D (2008) Molecular biology of 5-HT receptors. Behav Brain Res 195:198-213

Hanson MA, Brooun A, Baker KA, Jaakola VP, Roth C, Chien EY, Alexandrov A, Velasquez J, Davis L, Griffith M, Moy K, GanserPornillos BK, Hua Y, Kuhn P, Ellis S, Yeager M, Stevens RC (2007) Profiling of membrane protein variants in a baculovirus system by coupling cell-surface detection with smallscale parallel expression. Protein Expr Purif 56:85-92

Huang XP, Karpiak J, Kroeze WK, Zhu H, Chen X, Moy SS, Saddoris KA, Nikolova VD, Farrell MS, Wang S, Mangano TJ, Deshpande DA, Jiang A, Penn RB, Jin J, Koller BH, Kenakin T, Shoichet BK, Roth BL (2015) Allosteric ligands for the pharmacologically dark receptors GPR68 and GPR65. Nature 527:477-483

Isberg V, Mordalski S, Munk C, Rataj K, Harpsøe K, Hauser AS, Vroling B, Bojarski AJ, Vriend G, Gloriam DE (2016) GPCRdb: an information system for $G$ protein-coupled receptors. Nucleic Acids Res 44:D356-D364

Jacobson KA (2015) New paradigms in GPCR drug discovery. Biochem Pharmacol 98:541-555

Jang HJ, Cho KH, Park SW, Kim MJ, Yoon SH, Rhie DJ (2012) Layerspecific serotonergic facilitation of IPSC in layer $2 / 3$ pyramidal neurons of the visual cortex. J Neurophysiol 107:407-416

Kroeze WK, Sassano MF, Huang XP, Lansu K, McCorvy JD, Giguère PM, Sciaky N, Roth BL (2015) PRESTO-Tango as an opensource resource for interrogation of the druggable human GPCRome. Nat Struct Mol Biol 22:362-369

Lv X, Liu J, Shi Q, Tan Q, Wu D, Skinner JJ, Walker AL, Zhao L, Gu X, Chen N, Xue L, Si P, Zhang L, Wang Z, Katritch V, Liu ZJ, Stevens RC (2016) In vitro expression and analysis of the 826 human G protein-coupled receptors. Protein Cell 7:325-337

McCorvy JD, Roth BL (2015) Structure and function of serotonin G protein-coupled receptors. Pharmacol Ther 150:129-142

Narayanaswami V, Dwoskin LP (2016) Obesity: current and potential pharmacotherapeutics and targets. Pharmacol Ther 170:116-147

Newman DJ, Cragg GM (2016) Natural Products as sources of new drugs from 1981 to 2014. J Nat Prod 79:629-661

Nichols DE, Frescas S, Marona-Lewicka D, Kurrasch-Orbaugh DM (2002) Lysergamides of isomeric 2,4-dimethylazetidines map the binding orientation of the diethylamide moiety in the potent hallucinogenic agent $\mathrm{N}, \mathrm{N}$-diethyllysergamide (LSD). J Med Chem 45:4344-4349

Qin S, Ren Y, Fu X, Shen J, Chen X, Wang Q Bi X, Liu W, Li L, Liang G, Yang C, Shui W (2015) Multiple ligand detection and affinity measurement by ultrafiltration and mass spectrometry analysis applied to fragment mixture screening. Anal Chim Acta 886:98-106

Rask-Andersen M, Masuram S, Schioth HB (2014) The druggable genome: evaluation of drug targets in clinical trials suggests major shifts in molecular class and indication. Annu Rev Pharmacol Toxicol 54:9-26

Santos R, Ursu O, Gaulton A, Bento AP, Donadi RS, Bologa CG, Karlsson A, Al-Lazikani B, Hersey A, Oprea TI, Overington JP 
(2017) A comprehensive map of molecular drug targets. Nat Rev Drug Discov 16:19-34

Shang JH, Cai XH, Feng T, Zhao YL, Wang JK, Zhang LY, Yan M, Luo XD (2010) Pharmacological evaluation of Alstonia scholaris: anti-inflammatory and analgesic effects. J Ethnopharmacol 129:174-181

Venkatakrishnan AJ, Deupi X, Lebon G, Tate CG, Schertler GF, Babu MM (2013) Molecular signatures of G-protein-coupled receptors. Nature 494:185-194

Wacker D, Wang C, Katritch V, Han GW, Huang XP, Vardy E, McCorvy JD, Jiang Y, Chu M, Siu FY, Liu W, Xu HE, Cherezov V, Roth BL, Stevens RC (2013) Structural features for functional selectivity at serotonin receptors. Science 340:615-619

Wacker D, Wang S, McCorvy JD, Betz RM, Venkatakrishnan AJ, Levit A, Lansu K, Schools ZL, Che T, Nichols DE, Shoichet BK, Dror RO, Roth BL (2017) Crystal structure of an LSD-bound human serotonin receptor. Cell 168(377-389):e312

Wang C, Jiang Y, Ma J, Wu H, Wacker D, Katritch V, Han GW, Liu W, Huang XP, Vardy E, McCorvy JD, Gao X, Zhou XE, Melcher K,
Zhang C, Bai F, Yang H, Yang L, Jiang H, Roth BL, Cherezov V, Stevens RC, Xu HE (2013) Structural basis for molecular recognition at serotonin receptors. Science 340:610-614

Xu X, Wang ZT, Yu GD, Ruan BF, Li J (2002) Alkaloids from Rhizoma corydalis. Journal of China Pharm Univ 33:483-486

Yin X, Bai R, Guo Q, Su G, Wang J, Yang X, Li L, Tu P, Chai X (2016) Hendersine A, a novel isoquinoline alkaloid from Corydalis hendersonii. Tetrahedron Lett 57:4858-4862

Yuan S, Peng Q Palczewski K, Vogel H, Filipek S (2016) Mechanistic studies on the stereoselectivity of the serotonin 5-HT1A receptor. Angew Chem Int Ed Engl 55:8661-8665

Zeeb FD, Higgins GA, Fletcher PJ (2015) The serotonin 2C receptor agonist lorcaserin attenuates intracranial self-stimulation and blocks the reward-enhancing effects of nicotine. ACS Chem Neurosci 6:1231-1240

Zhong M, Jiang YB, Chen YL, Yan Q Liu JX, Di DL (2015) Asymmetric total synthesis of $(S)$-isocorydine. Tetrahedron 26:1145-1149 